\title{
Testosterone Excess
}

National Cancer Institute

\section{Source}

National Cancer Institute. Testosterone Excess. NCI Thesaurus. Code C113349.

Abnormally high level of testosterone. 